\title{
Brachial plexus block with midazolam and bupiva- caine improves analgesia
}

\author{
[Le bloc du plexus brachial avec du midazolam et de la bupivacä̈ne améliore \\ l'analgésie]
}

Koj Jarbo MD, Yatindra Kumar Batra MD MNAMs, Nidhi Bidyut Panda MD

Purpose: Adjuncts to local anesthetics for brachial plexus block may enhance the quality and duration of analgesia. Midazolam, a water-soluble benzodiazepine, is known to produce antinociception and enhance the effect of local anesthetics when given epidurally or intrathecally. The purpose of this study was to assess the effect of midazolam added to brachial plexus anesthesia.

Methods: A prospective, randomized, double blind study was conducted on 40 ASA I or II adult patients undergoing upper limb surgeries under supraclavicular brachial plexus block. Patients were randomly divided into two groups. Patients in Group B $(n=20)$ were administered $30 \mathrm{~mL}$ of $0.5 \%$ bupivacaine and Group BM $(n=20)$ were given $30 \mathrm{~mL}$ of $0.5 \%$ bupivacaine with midazolam $50 \mu \mathrm{g} \cdot \mathrm{kg}^{-1}$. Hemodynamic variables (i.e., heart rate, noninvasive blood pressure), pain scores and rescue analgesic requirements were recorded for $24 \mathrm{hr}$ postoperatively.

Results: The onset of sensory and motor block was significantly faster in Group BM compared to Group B $(P<0.05)$. Pain scores were significantly higher in Group B compared to Group BM from two hours to $24 \mathrm{hr}$ postoperatively $(P<$ $0.05)$. Rescue analgesic requirements were significantly less in Group BM compared to Group B $(P<0.05)$. Hemodynamics and sedation scores did not differ between groups in the postoperative period.

Conclusion: Midazolam $\left(50 \mu \mathrm{g} \cdot \mathrm{kg}^{-1}\right)$ in combination with 30 $\mathrm{mL}$ of bupivacaine $(0.5 \%)$ hastened onset of sensory and motor block, and improved postoperative analgesia when used in brachial plexus block, without producing any adverse events.
Objectif: Un ajout aux anesthésiques locaux pour le bloc du plexus brachial peut améliorer la qualité et la durée de l'analgésie. Le midazolam, une benzodiazépine hydrosoluble, administré par voie péridurale ou intrathécale, produit de l'antinociception et améliore l'effet des anesthésiques locaux. Nous avons évalué l'effet du midazolam ajouté à l'anesthésie du plexus brachial.

Méthode : Une étude prospective, randomisée et à double insu a été menée auprès de 40 adultes d'état physique ASA I ou II devant être opérés aux membres supérieurs sous anesthésie supraclaviculaire du plexus brachial. Les patients ont été répartis aléatoirement en deux groupes. Ceux du groupe $B(n=20)$ ont reçu $30 \mathrm{~mL}$ de bupivacaïne à $0,5 \%$ et ceux du groupe $B M(n=20)$ ont eu 30 $\mathrm{mL}$ de bupivacaïne à $0,5 \%$ avec $50 \mu \mathrm{g} \cdot \mathrm{kg}^{-1}$ de midazolam. Les variables hémodynamiques, les scores de douleur et les demandes d'analgésiques de secours ont été notés pendant $24 h$ après l'opération.

Résultats : Le délai d'installation du bloc sensitif et moteur a été significativement plus court chez les patients du groupe BM, comparé au groupe $B(P<0,05)$. De $2 h$ à $24 h$ après l'opération, les douleurs ont été plus importantes dans le groupe $B(P<0,05)$ et les demandes d'analgésiques de secours ont été moindres dans le groupe $B M(P<0,05)$. Après l'opération, l'hémodynamique et les scores de sédation ne différaient pas d'un groupe à l'autre.

Conclusion : Le midazolam $\left(50 \mu \mathrm{g} \cdot \mathrm{kg}^{-1}\right)$ combiné à $30 \mathrm{~mL}$ de bupivacaïne $(0,5 \%)$ a accéléré l'installation du bloc sensitif et moteur et amélioré l'analgésie postopératoire sans produire d'effets indésirables lors du bloc du plexus brachial.

From the Department of Anesthesia and Intensive Care Unit, Postgraduate Institute of Medical Education and Research, Chandigarh, India. Address correspondence to: Dr. Yatindra Kumar Batra, Anesthesia and Intensive Care unit, Postgraduate Institute of Medical Education and Research, Chandigarh-160012, India. Phone: +91-172-2715545; Fax: +91-172-2744401; E-mail: ykbatra@glide.net.in Accepted for publication January 11, 2005. Revision accepted March 28, 2005. 
$\mathrm{B}$ RACHIAL plexus blocks provide a useful alternative to general anesthesia for upper limb surgery. They achieve ideal operating conditions by producing complete muscular relaxation, maintaining stable intraoperative hemodynamics, and the associated sympathetic block. The sympathetic block decreases postoperative pain, vasospasm and edema. ${ }^{1,2}$ Of various local anesthetics used for brachial plexus block, bupivacaine is used most frequently, as it has a long duration of action varying from three to eight hours. ${ }^{1-4}$ Any adjunct to brachial plexus block should prolong the analgesic effect without incurring systemic side effects or prolonged motor block, and should also reduce the total dose of local anesthetic. Various studies have investigated several adjuncts, including opioids, clonidine, neostigmine, hyaluronidase, and bicarbonate..$^{5-9}$ The results have been inconclusive, because of associated side effects or doubtful efficacy. Midazolam, a water-soluble benzodiazepine, is known to produce antinociception and to enhance the effect of local anesthetic when given epidurally or intrathecally. Midazolam produces this effect by its action on gamma aminobutyric acid-A (GABA-A) receptors. ${ }^{10-12}$ GABA receptors have also been found in peripheral nerves. ${ }^{13-15}$ However, the effect of adding midazolam to a local anesthetic solution in peripheral nerve blocks has not been studied. We therefore sought to determine the onset time and anagesic efficacy of midazolam-bupivacaine combination compared to plain bupivacaine $0.5 \%$ for brachial plexus block.

\section{Methods}

A prospective, randomized, observer blinded study was undertaken. After receiving Institutional Ethical Committee approval and written informed consent, 40 ASA I or II adult patients scheduled for forearm and hand surgery after trauma were included in the study. All patients were premedicated with diazepam $5 \mathrm{mg}$ orally one hour before surgery. Brachial plexus block was performed by a senior and experienced anesthesiologist using a supraclavicular approach. Study drugs were prepared by an anesthesiologist not involved in performing the block, in patient care, or data collection. The patient was placed in the supine position, with the head turned away and the ipsilateral arm adducted. The interscalene groove and mid-point of the clavicle were identified. After aseptic preparation of the area, at a point 1.5 to $2.0 \mathrm{~cm}$ posterior to midpoint of the clavicle, a skin wheal was raised with local anesthetic. Next, a 22-G, 4-cm "short beveled" needle was passed through the same point in a caudad, slightly medial and posterior direction, until either a paresthesia was elicited or the first rib was encountered. If the first rib was encountered, the needle was moved over the first rib until a paresthesia was elicited either in the hand or arm. After eliciting paresthesia and negative aspiration of blood, the study medication was injected.

The patients were randomly divided into two groups. Patients in Group B $(n=20)$ received $30 \mathrm{~mL}$ of $0.5 \%$ bupivacaine while those in Group BM $(n=$ 20) received $30 \mathrm{~mL}$ of bupivacaine $0.5 \%$ along with preservative free midazolam $50 \mu \mathrm{g} \cdot \mathrm{kg}^{-1}$ (Neon laboratories Ltd., Mumbai, India). The patient and anesthesiologist observer were blinded to the test drug administered. The observer monitored the anesthesia and analgesia up to $24 \mathrm{hr}$ in the postoperative period in all 40 patients. The assessment for onset of sensory and motor block was done every minute from the time of injection of test drug until the block was established. Sensory block was evaluated by temperature testing using spirit soaked cotton on skin dermatomes C4-T2, whereas motor block was assessed by asking the patient to adduct the shoulder and flex the forearm and hand against gravity. ${ }^{9}$ Onset of sensory block was defined as the time elapsed between injection of drug and complete loss of cold perception of the hand, while onset of motor block was defined as the time elapsed from injection of drug to complete motor block. Only patients with complete motor block were included in the study. Sedation was assessed using the sedation score described by Culebras et al. ${ }^{6}$ (1- awake and alert, 2 - sedated, responding to verbal stimulus, 3- sedated, responding to mild physical stimulus, 4sedated, responding to moderate or severe physical stimulus, 5- not arousable). Heart rate, noninvasive blood pressure, oxygen saturation and sedation score were measured every five minutes until the end of surgery. Duration of sensory block (the time elapsed between injection of the drug and appearance of pain requiring analgesia), and duration of motor block (time elapsed between injection of the drug to complete return of motor power) were also recorded. Pain was assessed using a numerical rating pain score scale where zero (0) represents no pain, and 100 means the worst possible pain. Fentanyl $2 \mu \mathrm{g} \cdot \mathrm{kg}^{-1} i v$ was given as rescue analgesic when the pain score was more than 40. Postoperatively, heart rate, noninvasive blood pressure, pain and sedation scores were recorded at 0 min, $30 \mathrm{~min}, 2 \mathrm{hr}, 6 \mathrm{hr}, 12 \mathrm{hr}$ and $24 \mathrm{hr}$.

\section{Statistics}

Assuming 90\% statistical power and setting the level of significance at $5 \%$, a sample size of 17 per group was considered adequate to discern improvement in pain 
scores at $24 \mathrm{hr}$. To allow for any incomplete studies, we enrolled 20 patients in each group. An unpaired t test was used to compare demographic variables, intraoperative hemodynamic variables (heart rate, systolic blood pressure) oxygen saturation, and onset and duration of sensory and motor block between the groups. Sedation scores and pain scores were compared by Mann Whitney U test, while rescue analgesic requirements in both groups were compared by Chisquare test. A $P$ value less than 0.05 was considered statistically significant.

\section{Results}

Mean age, sex distribution, weight and duration of surgery were similar in both groups (Table I). Sensory and motor block appeared earlier in Group BM than in Group B $(P<0.05)$. In Group BM, onset of sensory block occurred in $12 \pm 2.9$ min compared to 20 $\pm 3.8 \mathrm{~min}$ in Group B. Onset time of motor block in Group BM was $9.2 \pm 2.38$ min compared to $17.1 \pm$ $3.83 \mathrm{~min}$ in Group B. In both groups, motor block occurred earlier than sensory block $(P<0.05)$ but the duration of motor block was not different between groups (Table II).

Postoperatively, lower pain scores were observed in Group BM compared to Group B for the 2 to $24 \mathrm{hr}$ postoperative period $(P<0.05)$, (Figure). All patients in Group B required rescue analgesia, while only three patients (15\%) of group BM required rescue analgesics $(P<0.05)$. The number of rescue analgesic doses required was significantly higher $(n=58)$ in Group B compared to Group BM $(n=8, P<0.05)$ during the study period.

Sedation scores differed between the groups $(P<$ 0.05 ) as patients in Group B were all awake (score l) throughout the intraoperative period, while in Group $\mathrm{BM}$, four patients at ten minutes and seven patients at $20 \mathrm{~min}$ were sedated and responded to verbal stimulation (score 2). In Group BM, the highest sedation score was 3 in one patient. No patient in Group $\mathrm{BM}$ required assistance for airway maintenance due to sedation. Sedation scores did not differ between groups in the postoperative period.

Heart rate, systolic blood pressure, diastolic blood pressure, mean arterial pressure, oxygen saturation were comparable between groups and did not change significantly in the intraoperative or postoperative period. No adverse events were encountered in either group of patients.

\section{Discussion}

Brachial plexus block provides postoperative analgesia of short duration, even when a long-acting local anes-
TABLE I Demographic characteristics (mean \pm SD)

\begin{tabular}{lll}
\hline & Group B $(n=20)$ & $\begin{array}{l}\text { Group BM } \\
(n=20)\end{array}$ \\
Age $(\mathrm{yr})$ & $33.2 \pm 9.29$ & $33.65 \pm 9.34$ \\
Weight $(\mathrm{kg})$ & $60.00 \pm 5.3$ & $58.1 \pm 5.2$ \\
M:F & $15: 5$ & $13: 7$ \\
$\begin{array}{l}\text { Duration of sur- } \\
\text { gery (min) }\end{array}$ & $92.8 \pm 27.82$ & $88.58 \pm 25.84$ \\
& &
\end{tabular}

Group B = were administered bupivacaine; Group BM = were administered bupivacaine and midazolam.

TABLE II Characteristics of sensory and motor blocks

\begin{tabular}{|c|c|c|c|c|c|}
\hline & & \multicolumn{2}{|c|}{ Sensory block } & \multicolumn{2}{|c|}{ Motor block } \\
\hline & & Group B & $\begin{array}{l}\text { Group } \\
\text { BM }\end{array}$ & Group B & Group BM \\
\hline \multirow{2}{*}{$\begin{array}{l}\text { Onset } \\
\text { of block } \\
(\mathrm{min})\end{array}$} & $\begin{array}{l}\text { Mean } \\
\pm S D\end{array}$ & $20 \pm 3.8$ & $\begin{array}{l}12 \pm \\
2.9^{*}\end{array}$ & $\begin{array}{l}17.1 \pm \\
3.83\end{array}$ & $\begin{array}{l}9.2 \pm \\
2.38 \text { * }\end{array}$ \\
\hline & Range & $15-30$ & $8-15$ & $8-25$ & $6-15$ \\
\hline \multirow{2}{*}{$\begin{array}{l}\text { Duration } \\
\text { of block } \\
\text { (hr) }\end{array}$} & $\begin{array}{l}\text { Mean } \\
\pm \text { SD }\end{array}$ & $\begin{array}{l}5.95 \pm \\
1.4\end{array}$ & $7 \pm 4.32$ & $\begin{array}{l}5.1 \pm \\
1.14\end{array}$ & $\begin{array}{l}5.65 \pm \\
3.32\end{array}$ \\
\hline & Range & $4-8$ & $4-24$ & $4-8$ & $3-18$ \\
\hline
\end{tabular}

Group B = were administered bupivacaine; Group BM = were administered bupivacaine and midazolam. ${ }^{*}$ Different from Group B, $P<0.05$.

thetic like bupivacaine is used alone. Various adjuvant drugs have been evaluated in conjunction with local anesthetics to prolong the period of analgesia, ${ }^{5-9}$ but they were found to be either ineffective or to produce an unacceptably high incidence of adverse effects. To date there is no study on the effect of adding midazolam to the analgesic characteristics produced by local anesthetics in peripheral nerve blocks. In our study we found that the onset of sensory and motor blocks was significantly faster in patients who received a combination of midazolam and bupivacaine. This could be due to a local anesthetic property of midazolam and its synergistic action with that of local anesthetics. ${ }^{10-12}$ The onset of motor block was found to be faster than the onset of sensory block in both groups. Winnie et al. ${ }^{16}$ observed this also, and attributed this to the 


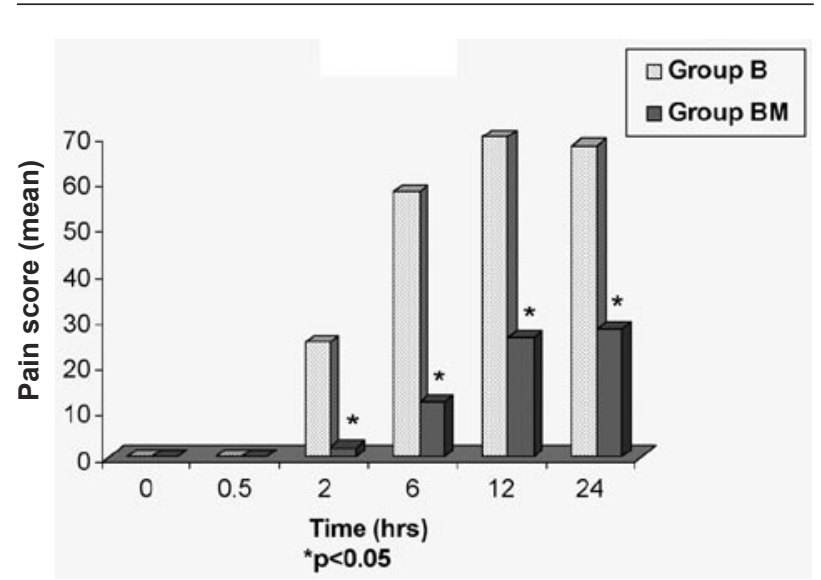

FIGURE Postoperative pain score in both groups (mean).

somatotrophic arrangement of fibres in a nerve bundle at the level of the trunks in which motor fibres are located more peripherally than sensory fibres. Hence, a local anesthetic injected perineurally will begin to block motor fibres before it arrives at the centrally located sensory fibres.

Our results showed that sensory block tended to last longer as compared to motor block which agrees with the observation by de Jong et al. ${ }^{3}$ These authors explained that large fibres require a higher concentration of local anesthetic than small fibres. The minimal effective concentration of local anesthetic for large (motor) fibres is greater than for small (sensory) fibres. Thus, motor function return before pain perception and duration of motor block is shorter than the sensory block. ${ }^{3}$ However, in our study duration of sensory and motor blocks were not different between the groups.

Various studies in which midazolam was used in central neuraxial block found that midazolam with bupivacaine improves analgesic characteristics compared to bupivacaine alone. ${ }^{10-12}$ Gulec et al. ${ }^{17}$ found that a bupivacaine and midazolam combination prolonged postoperative analgesia compared to a bupivacaine-morphine combination when administered caudally. Nishiyama et al. ${ }^{11}$ added midazolam to a continuous epidural infusion of bupivacaine and observed improved analgesia. Batra et al. ${ }^{18}$ used bupivacaine with midazolam intrathecally and found a significantly lower visual analogue score compared to bupivacaine alone. Midazolam produces this additive effect on local anesthetics by its action on the GABA-A receptor complexes present in the spinal cord. ${ }^{10-12}$ The addition of midazolam in doses of approximately $\mathrm{l}$ to $2 \mathrm{mg}$ intrathecally has a positive effect on perioperative and chronic pain therapy. ${ }^{19}$ Studies in animals have revealed no neurotoxic effects of intrathecally administered midazolam. ${ }^{20-22}$ More recently, Tucker and associates demonstrated that the administration of intrathecal midazolam causes potentiation of the analgesic effect of intrathecal fentanyl in labouring patients. ${ }^{23}$ The administration of intrathecal midazolam, $2 \mathrm{mg}$, did not increase the occurrence of neurologic or urologic symptoms. ${ }^{24}$

In our study, pain scores were significantly lower in patients who received midazolam in addition to bupivacaine. The number of patients who required rescue analgesia and the mean number of supplemental analgesic boluses required were also significantly lower in patients in Group BM. The prolonged analgesia in Group BM could be due to the action of midazolam on GABA-A receptors present in the brachial plexus and thus producing antinociception. Various authors have demonstrated the presence of GABA receptors in peripheral nerves. Brown and Marsh demonstrated GABA receptors in mammalian peripheral nerve trunk. ${ }^{13}$ Bhisitkul et al. showed that axonal GABA receptors are present on both normal and regenerated sensory fibres in rat peripheral nerve. ${ }^{14}$ Cairns et al. observed the presence of GABA receptors within the tempromandibular joint and that its activation could decrease the transmission of nociceptive signals. ${ }^{15}$ The action of midazolam on GABA receptors is well established.

We studied midazolam at a dose of $50 \mu \mathrm{g} \cdot \mathrm{kg}^{-1}$, as others have used the same dosage in central neuraxial block without any significant adverse effects. ${ }^{17,18} \mathrm{In}$ our study, sedation scores were higher in patients in Group BM compared to Group B, 15 min after injecting the drug until 30 min postoperatively. This may have been due to partial vascular uptake of the drug (midazolam), and its transport to the central nervous system where it acts and produces sedation. ${ }^{25}$ The limited duration of sedation could be explained by the fact that midazolam is highly lipophilic and diffuses faster into the blood vessels, by its rapid clearance (6-11 $\left.\mathrm{mL} \cdot \mathrm{kg}^{-1} \cdot \mathrm{min}^{-1}\right)$ and short half-life $(1.7-2.6$ hr). ${ }^{25}$ Though mean sedation score in group BM was higher as compared to group B $(P<0.05)$, we did not observe clinically significant sedation in patients in Group BM. The highest sedation score was 3; i.e., the patient was asleep and arousable by mild physical stimulation. No patient experienced airway compromise or required airway assistance.

In conclusion, midazolam $50 \mu \mathrm{g} \cdot \mathrm{kg}^{-1}$ when added to $30 \mathrm{~mL}$ of bupivacaine $0.5 \%$ for supraclavicular 
brachial plexus block, speeds the onset of sensory and motor blocks $(P<0.05)$. The combination produces improved analgesia, as manifested by lower pain scores, a prolonged effect and reduced requirements for rescue analgesics.

\section{References}

1 Lund PC, Cwik JC, Vallesteros F. Bupivacaine- a new long-acting local anesthetic agent. A preliminary clinical and laboratory report. Anesth Analg 1976; 49: 103-13.

2 De Jong $R H$. Axillary block of brachial plexus. Anesthesiology 1961; 22: 215-25.

3 de Jong RH, Wagman IH. Physiological mechanisms of peripheral nerve block by local anesthetics. Anesthesiology 1963; 24: 684-727.

4 McGlade DP, Kalpokas MV, Mooney PH, Chamley D, Mark AH, Torda TA. A comparison of $0.5 \%$ ropivacaine and $0.5 \%$ bupivacaine for axillary brachial plexus anesthesia. Anaesth Intensive Care 1998; 26: 515-20.

5 Bazin JE, Massoni C, Bruelle P, Fenies V, Groslier D, Schoeffler $P$. The addition of opioids to local anaesthetics in brachial plexus block: the comparative effects of morphine, buprenorphine, and sufentanil. Anaesthesia 1997; 52: 858-62.

6 Culebras X, Van Gessel E, Hoffmeyer P, Gamulin Z. Clonidine combined with a long acting local anaesthetic does not prolong postoperative analgesia after brachial plexus block but does induce hemodynamic changes. Anesth Analg 2001; 92: 199-204.

7 Bone HG, Van Aken H, Brooke M, Burkle H. Enhancement of axillary brachial plexus block anesthesia by coadministration of neostigmine. Reg Anesth Pain Med 1999; 24: 405-10.

8 Keeler JF, Simpson KH, Ellis FR, Kay SP. Effect of addition of hyaluronidase to bupivacaine during axillary brachial plexus block. Br J Anaesth 1992; 68: 68-71.

9 Bedder MD, Kozody R, Craig DB. Comparison of bupivacaine and alkalinized bupivacaine in brachial plexus anesthesia. Anesth Analg 1988; 67: 48-52.

10 Edwards M, Serrao JM, Gent JP, Goodchild CS. On the mechanism by which midazolam causes spinally mediated analgesia. Anesthesiology 1990; 73: 273-7.

11 Nishiyama T, Yokoyama T, Hanaoka K. Midazolam improves postoperative epidural analgesia with continuous infusion of local anaesthetics. Can J Anaesth 1998; 45: 551-5.

$12 \mathrm{Kim} M H$, Lee $Y M$. Intrathecal midazolam increases the analgesic effects of spinal blockade with bupivacaine in patients undergoing haemorrhoidectomy. Br J Anaesth 2001; 86: 77-9.

13 Brown DA, Marsh $S$. Axonal GABA-receptors in mammalian peripheral nerve trunks. Brain Res 1978; 156: 187-91.
14 Bhisitkul RB, Villa JE, Kocsis JD. Axonal GABA receptors are selectively present on normal and regenerated sensory fibers in rat peripheral nerves. Exp Brain Res 1987; 66: 659-63.

15 Cairns BE, Sessle BJ, Hu JW. Activation of peripheral $\mathrm{GABA}_{\mathrm{A}}$ receptors inhibits temporomandibular jointevoked jaw muscle activity. J Neurophysiol 1999; 81: 1966-9.

16 Winnie AP, Tay CH, Patel KP, Ramamurthy S, Durrani $Z$. Pharmacokinetics of local anaesthetics during plexus blocks. Anesth Analg 1977; 56: 852-61.

17 Gulec S, Buyukkidan B, Oral N, Ozcan N, Tanriverdi $B$. Comparison of caudal bupivacaine, bupivacainemorphine and bupivacaine-midazolam mixtures for post-operative analgesia in children. Eur J Anaesthesiol 1998; 15: 161-5.

18 Batra YK, Jain K, Chari P, Dhillon MS, Shabeen B, Reddy GM. Addition of intrathecal midazolam to bupivacaine produces better post-operative analgesia without prolonging recovery. Int J Clin Pharmacol Ther 1999; 37: 519-23.

19 Serrao JM, Marks RL, Morley SJ, Goodchild CS. Intrathecal midazolam for the treatment of chronic mechanical low back pain: a controlled comparison with epidural steroid in a pilot study. Pain 1992; 48: 5-12.

20 Serrao JM, MacKenzie JM, Goodchild CS, Gent JP. Intrathecal midazolam in the rat: an investigation of possible neurotoxic effects. Eur J Pharmacol 1990; 7: 115-22.

21 Nishiyama T, Matsukawa T, Hanaoka K. Acute phase histopathological study of spinally administered midazolam in cats. Anesth Analg 1999; 89: 717-20.

22 Schweiger IM, Jorge-Costa M, Pizzolato GP, Foster A, Morel DR. Intrathecal midazolam reduces isoflurane MAC and increases the apnoeic threshold in rats. Can J Anaesth 1994; 41: 144-8.

23 Tucker AP, Mezzatesta J, Nadeson R, Goodchild CS. Intrathecal midazolam II: combination with intrathecal fentanyl for labor pain. Anesth Analg 2004; 98: 1521-7.

24 Tucker AP, Lai C, Nadeson R, Goodchild CS. Intrathecal midazolam I: a cohort study investigating safety. Anesth Analg 2004; 98: 1512-20.

25 Reeves JG, Fragen RJ, Vinik HR, Greenblatt DJ. Midazolam: phamacology and uses. Anesthesiology 1985; 62: 310-24. 